\title{
Archive of bacterial community in anhydrite crystals from a deep-sea basin provides evidence of past oil-spilling in a benthic environment in the Red Sea
}

\author{
Yong Wang ${ }^{1,2}$, Tie Gang $\mathrm{Li}^{3,4}$, Meng Ying Wang ${ }^{1}$, Qi Liang Lai ${ }^{5}$, Jiang Tao $\mathrm{Li}^{6}$, Zhao Ming Gao ${ }^{1}$, Zong Ze Shao ${ }^{5}$, and \\ Pei-Yuan Qian ${ }^{2}$ \\ ${ }^{1}$ Institute of Deep-Sea Science and Engineering, Chinese Academy of Sciences, San Ya, China \\ ${ }^{2}$ Division of Life Science, Hong Kong University of Science and Technology, Clear Water Bay, Hong Kong, China \\ ${ }^{3}$ Key Laboratory of Marine Sedimentology and Environmental Geology, First Institute of Oceanography, \\ State of Oceanic Administration (SOA), Qingdao, China \\ ${ }^{4}$ Laboratory for Marine Geology, Qingdao National Laboratory for Marine Science and Technology, Qingdao, China \\ ${ }^{5}$ Key Laboratory of Marine Biogenetic Resources, The Third Institute of Oceanography, SOA, Xiamen, China \\ ${ }^{6}$ State Key Laboratory of Marine Geology, Tongji University, Shanghai, China \\ Correspondence to: Pei-Yuan Qian (boqianpy@ust.hk) and Yong Wang (wangy@idsse.ac.cn)
}

Received: 12 May 2016 - Published in Biogeosciences Discuss.: 18 July 2016

Revised: 17 October 2016 - Accepted: 15 November 2016 - Published: 30 November 2016

\begin{abstract}
In deep-sea sediment, the microbes present in anhydrite crystals are potential markers of the past environment. In the Atlantis II Deep, anhydrite veins were produced by mild mixture of calcium-rich hydrothermal solutions and sulfate in the bottom water, which had probably preserved microbial inhabitants in the past seafloor of the Red Sea. In this study, this hypothesis was tested by analyzing the metagenome of an anhydrite crystal sample from the Atlantis II Deep. The estimated age of the anhydrite layer was between 750 and 770 years, which might span the event of hydrothermal eruption into the benthic floor. The $16 \mathrm{~S} / 18 \mathrm{~S}$ rRNA genes in the metagenome were assigned to bacteria, archaea, fungi and even invertebrate species. The dominant species in the crystals was an oil-degrading Alcanivorax borkumensis bacterium, which was not detected in the adjacent sediment layer. Fluorescence microscopy using $16 \mathrm{~S}$ rRNA and marker gene probes revealed intact cells of the Alcanivorax bacterium in the crystals. A draft genome of $A$. borkumensis was binned from the metagenome. It contained all functional genes for alkane utilization and the reduction of nitrogen oxides. Moreover, the metagenomes of the anhydrites and control sediment contained aromatic degradation pathways, which were mostly derived from Ochrobactrum sp. Altogether, these results indicate an oxic, oil-spilling benthic environment in the Atlantis II basin of the Red Sea in ap-
\end{abstract}

proximately the 14 th century. The original microbial inhabitants probably underwent a dramatic selection process via drastic environmental changes following the formation of an overlying anoxic brine pool in the basin due to hydrothermal activities.

\section{Introduction}

Deep-sea sediment is among the least explored biospheres on Earth. Indigenous microbes differ vastly in community composition and metabolic spectra at different depths and sites (Orcutt et al., 2011; Teske and Sorensen, 2007). The distribution of microbes in subsuperficial sediments is determined by the porosity, nutrient availability and geochemical conditions of the sediment (Parkes et al., 2000; Webster et al., 2006). In return, genomic features and the community composition of the indigenous microbial inhabitants may reflect the in situ conditions and serve as biomarkers containing the geochemical indicators. However, most of the biomarkers cannot be well preserved and will be degraded by biological and abiological activities. Although lipids and other organic carbons present in some minerals allow the interpretation of microbial activities to some extent (Brocks et al., 2005), the orig- 
inal metabolic activities are difficult to retrieve in a comprehensive and precise manner.

Most of the dead microbes are damaged during the sedimentation process, but some can be maintained in almost their original shape (Taher, 2014; Benison et al., 2008). Evaporites, which mostly consist of halite and anhydrite $\left(\mathrm{CaSO}_{4}\right)$ or gypsum $\left(\mathrm{CaSO}_{4} \times 2 \mathrm{H}_{2} \mathrm{O}\right.$, temperature $<38^{\circ}$; Hill, 1937), are common microbialites with accretionary organosedimentary structures (Dupraz et al., 2011). Numerous dead bacteria, algae and metazoans have been detected in gypsum granules (Petrash et al., 2012; Trichet et al., 2001); bacterial mats growing on evaporites may become trapped and constitute much larger microbialites (Babel, 2004). Consequently, microbial inhabitants on the benthic surface may get trapped in the evaporites (Benison et al., 2008). Anhydrite facies are not found throughout deep-sea sediments. They usually form around hydrothermal vents in deep-sea environments (Jannasch and Mottl, 1985). A strong deep-sea volcanic eruption may break the crustal basalts, resulting in a drastic emission of hydrothermal gases followed by the crystallization of anhydrites and the deposition of metal sulfides (Kristall et al., 2006). An alternative model is that mild hydrothermal activities lead to a slow influx of solutions into the overlying sediment at temperatures in the sub-seafloor ranging from 20 to $100{ }^{\circ} \mathrm{C}$. This process also results in the formation of crystalline anhydrites in veins and around warm vents (Jannasch and Mottl, 1985). The latter process may trap microbial inhabitants on the seafloor and within surface layers in anhydrites. Due to the mild temperature, the trapped bodies are better preserved as excellent biological evidence for past geochemical conditions.

A similar mild hydrothermal field is present in the Red Sea. Initially found in a deep-sea rift in the 1960s (Swallow and Crease, 1965; Girdler, 1970), the temperature of the Atlantis II brine pool has recently increased to $68^{\circ} \mathrm{C}$ (Anschutz and Blanc, 1996). In 1972, several sediment cores were obtained from the southwestern region of the pool (DSDP Site226), and metal sulfides and evaporites were recognized as major mineral facies in this brine-filled basin (Shipboard Scientific Party, 1974). In particular, thick and wellcrystalized anhydrite layers were found within the hematite and at the bottom of the cores. Two major anhydrite units were later defined by analysis of the adjacent core samples. The lower unit comprised anhydrite ranging from 12 to $70 \mathrm{wt} \%$ (Anschutz et al., 2000). The anhydrite in the sediments likely resulted from a geyser-type eruption of hydrothermal solutions into the Atlantis II brine pool followed by the mixing of calcium-rich solutions with dissolved sulfate-bearing brine and the precipitation of anhydrites during the cooling process (Ramboz et al., 1988). The discovery of veins containing sulfides and anhydrite in the sediment suggests that a mild hydrothermal eruption created the anhydrite facies in the Atlantis II sediment (Zierenberg and Shanks, 1983; Oudin et al., 1984; Missack et al., 1989). The formation of anhydrite facies in this manner would trap mi- crobial cells and organic debris in the bottom water and surface sediment. These anhydrite layers probably contained important indigenous microbial inhabitants during the occurrence of the hydrothermal events on the deep-sea benthic floor of the Red Sea. Coupled with ${ }^{14} \mathrm{C}$ markers to estimate age, the anhydrite facies contained a large quantity of information regarding past geochemical changes. The formation process of the Atlantis II brine pool is still controversial, largely because the source of the brine is uncertain (Schardt, 2016). The brine water had converted the bottom of the deep into a hot anoxic hypersaline environment. The microbes in the anhydrite facies may provide hints about the original benthic conditions and age of the pool. It is also an interesting question whether oil was generated in the sediments under the mild hydrothermal activities in the past. If yes, seeping hydrothermal solutions may bring oil into the seafloor of the deep, which might be documented by the microbes in the anhydrites.

In the present study, we sampled a sediment core near Site226 and detected an anhydrite layer. The dominant species were alkane- and oil-degrading bacteria indicating an oxic, oil-spilling benthic condition when the layer was formed. The present study sheds light on the importance of anhydrites in deep-sea sediment as an archive of microbial inhabitants that can serve as biomarkers of past geochemical events.

\section{Materials and methods}

\subsection{Physicochemical measurements of sediment layers}

In 2008 , a $2.25 \mathrm{~m}$ gravity sediment core was obtained from the southwestern basin (approximately $2180 \mathrm{~m}$ below sea level) of the Atlantis II Deep $\left(21^{\circ} 20.76^{\prime} \mathrm{N}, 38^{\circ} 04.68^{\prime} \mathrm{E}\right)$ in the Red Sea (Fig. S1 in the Supplement) (Bower, 2009). The core was frozen at $-80{ }^{\circ} \mathrm{C}$ and then sliced aseptically into 75 sections of $3 \mathrm{~cm}$ each. Microbes from sediment slices of 12-15, 63-66, 105-108, 183-186 and 222-225 cm were first suspended in phosphate-buffered saline and shaken by a vortexer for $30 \mathrm{~s}$. After $30 \mathrm{~min}$, the supernatant was filtered through a $0.22 \mu \mathrm{m}$ black polycarbonate filter. After 6-diamidino-2-phenylindole (DAPI) staining, the microbes from each layer were counted under an epifluorescence microscope $(n=3)$ (Gough and Stahl, 2003). The pore water from the top five layers was collected by centrifugation. The concentration of dissolved organic carbon (DOC) in the pore water was determined using the combustion method (Trichet et al., 2001). The concentrations of ammonium, nitrite and nitrate were measured using a TNM-I analyzer (Shimadzu Corp., Kyoto, Japan). To separate large particles $(>63 \mu \mathrm{m})$ from small particles $(<63 \mu \mathrm{m})$, the sediment samples were passed through a $63 \mu \mathrm{m}$ stainless steel sieve. The percentage of small particles (dry weight) was calculated for all slices. 
The age of the sections was estimated with a radiometric dating method that utilizes the naturally occurring radioisotope ${ }^{14} \mathrm{C}$. The monospecific Globigerinoides sacculifer specimens, ranging in size from 250 to $350 \mu \mathrm{m}$, were manually selected with caution and then subjected to ${ }^{14} \mathrm{C}$ measurement in the National Ocean Sciences Accelerator Mass Spectrometry (AMS) Facility at the Woods Hole Oceanographic Institute, USA. The raw AMS ${ }^{14} \mathrm{C}$ ages were converted to calendar ages using the CALIB 6.0 program (http: //calib.qub.ac.uk/calib/) with the dataset Marine 09 (Reimer et al., 2009). A reservoir correction has been considered for the ${ }^{14} \mathrm{C}$ difference between atmospheric and surface waters (Bard, 1988).

\subsection{DNA extraction and amplification}

The boundary of the anhydrite layer was determined by naked eye observation and particle size measurement. Crystals were manually collected from the layers, followed by ultrasonic cleaning. The homogenized crystals were then analyzed by X-ray diffraction (XRD) (Rigaku, Tokyo, Japan) using $\mathrm{Cu}$ K-alpha radiation of $40 \mathrm{kV}$ and $30 \mathrm{~mA}$. The following procedure was conducted for DNA extraction from the crystals with caution to avoid contamination. Surface contamination was removed by rinsing with $70 \%$ alcohol in autoclaved distilled deionized water, followed by pulsed ultrasonic cleaning for $2 \mathrm{~h}$. Anhydrite crystals (20 g) (Fig. 1a) of different sizes were treated with $1 \mu \mathrm{L}$ (2U) Turbo DNase I (Ambion, Austin, Texas, USA) for $30 \mathrm{~m}$ in a $37{ }^{\circ} \mathrm{C}$ incubation before being ground for DNA extraction in a sterile hood. The anhydrite powder was used for DNA extraction with the PowerSoil DNA Isolation Kit (MO BIO, Carlsbad, USA), followed by a purification step according to the manufacturer's instructions. The DNA concentration was quantified with a Quant-iT PicoGreen Kit (Invitrogen, USA). Of the raw DNA extract, $20 \mathrm{pg}$ was used for DNA amplification using a MALBAC kit (Yikon Genomics, Jiangsu, China) according to the manufacturer's manual (Zong et al., 2012). The MALBAC amplification method has been evaluated recently in metagenomic studies (Wang et al., 2016). Two MALBAC amplification assays were conducted using 21 PCR cycles to acquire a sufficient amount of DNA for subsequent sequencing. A negative control was also incorporated in the assay. The DNA concentration of the MALBACamplified sample and the negative control was measured with a Bioanalyzer (Agilent Technologies, CA, US). The products of the MALBAC amplification and negative control were examined by gel electrophoresis to confirm the size ranges of the amplicons. Three replicates of MALBAC amplifications for each sample were mixed and used for Illumina sequencing on a Hiseq2000 platform (Illumina, San Diego, US). As a control, $10 \mathrm{~g}$ of sediment from a position at $168 \mathrm{~cm}$ from the top of the core was used for DNA extraction. There were no recognizable anhydrite crystals in this layer. DNA sequencing was conducted as described above.
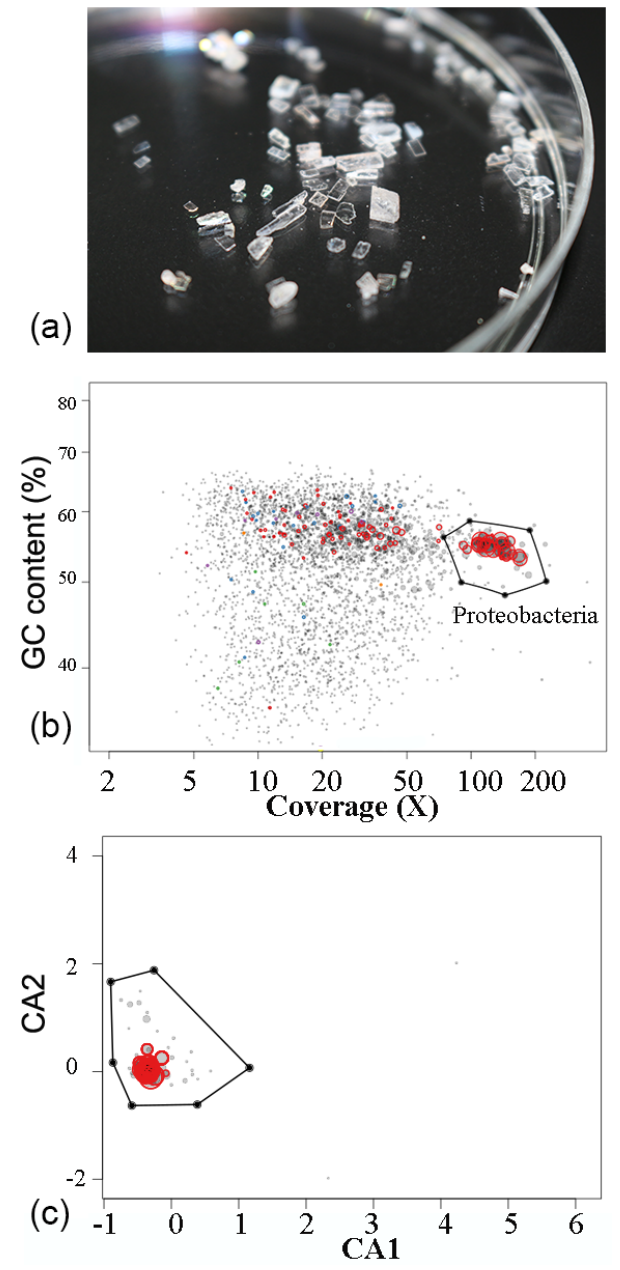

Figure 1. Anhydrite crystals and genome binning. Anhydrite crystals in a Petri dish $(90 \mathrm{~mm}$ in diameter) (a) were used for DNA extraction. The amplified genomic DNA was sequenced and then reassembled. Based on the $\mathrm{G}+\mathrm{C}$ content and read coverage, the binned contigs with high coverage levels (b) were selected for examination of the tetranucleotide frequency consistency in the PCA analysis (c).

\subsection{Binning of metagenomes}

The initial Illumina $2 \times 110$ bp paired-end reads were subjected to quality assessments using the NGS QC Toolkit with default parameters (Patel and Jain, 2012). The Illumina sequencing data were deposited in the NCBI SRA database (accession number SRA356974). The 35 bp MALBAC adapters at the two ends of the sequencing reads were removed. Assembly of the trimmed Illumina $2 \times 75$ bp paired-end reads was performed using SPAdes 3.5 (Nurk et al., 2013). The read coverage for the assembled contigs was calculated using SAMtools ( $\mathrm{Li}$ et al., 2009). The 16S/18S rRNA genes in the contigs were identified using rRNA_HMM (Huang et al., 2009). Using classify.seqs command in mothur package (Schloss et al., 2009), taxonomic sorting of the 16S rRNA 
genes was conducted against the SILVA database with a confidence threshold of $80 \%$. The relative abundance of the species in the metagenomes was roughly estimated based on the coverage of the $16 \mathrm{~S} / 18 \mathrm{~S}$ rRNA genes. Binning of the draft genomes was performed based on the read coverage and $\mathrm{G}+\mathrm{C}$ content of the contigs (Fig. 1b), followed by principal component analysis (PCA) of the tetranucleotide frequencies (TNF) of their respective contigs using a previously described pipeline (Fig. 1c) (Albertsen et al., 2013). The $\mathrm{R}$ scripts (R Core Team, 2013) for the binning process were obtained from https://github.com/MadsAlbertsen/ multi-metagenome. To evaluate the completeness of the draft genome, conserved single-copy genes (CSCGs) were counted in the genome. The CSCGs were identified by searching the CDSs (coding DNA sequences) against a database of essential bacterial genes (107 essential genes) (Albertsen et al., 2013) using hmmsearch (3.0) with default cutoffs for each protein family (Krogh et al., 1994).

\subsection{Genomic analyses}

The CDSs of the draft genome were predicted using Prodigal (version 2.60) (Hyatt et al., 2010). KEGG annotation of the CDSs was performed using BLASTp against the KEGG database (Kanehisa et al., 2012) with a maximum $e$-value cutoff of 1e-05. The KEGG pathways were reconstructed using the KEGG website (http://www.kegg.jp). CDSs were also annotated against the NCBI NR database, and MEGAN (MEtaGenome ANalyzer) was used for taxonomic affiliation and SEED/subsystem annotation of the CDSs (Overbeek et al., 2005). The draft genome was submitted to NCBI (accession number LKAP00000000). The average nucleotide identity (ANI) was calculated using the algorithm integrated in the web service of EzGenome (Goris et al., 2007). The DNADNA hybridization (DDH) estimate value was calculated using the genome-to-genome distance calculator (GGDC2.0) (Meier-Kolthoff et al., 2013; Auch et al., 2010a, b).

\subsection{Detection and phylogeny of $16 \mathrm{~S}$ ribosomal RNA (rRNA) genes}

The 16S rRNA gene sequence was identified from the draft genome sequence. The closest relatives based on $16 \mathrm{~S}$ sequence similarity were determined using the web service of EzTaxon (Kim et al., 2012). The neighbor-joining phylogenetic tree was constructed using MEGA version 5.0 (Tamura et al., 2011) with the Kimura 2-parameter model. The phylogenetic tree was supported with bootstrap values based on 1000 replications.

\subsection{Fluorescence in situ hybridization (FISH) of Alcanivorax bacteria}

FISH probes for 16S rRNA gene of Alcanivorax bacteria were designed based on the 16S rRNA gene sequence extracted from the Alcanivorax draft genome. Two $16 \mathrm{~S}$
rRNA fragments, $5^{\prime}$-CCTCTAATGGGCAGATTC- $3^{\prime}$ and $5^{\prime}$ CCCCCTCTAATGGGCAGA- $3^{\prime}$, were selected as candidate probes with Probe_Design in the ARB package (Ludwig et al., 2004). The coverage efficiency of the probes was then examined in the Silva database (Quast et al., 2013). The 6-FAM-labeled probe used to target the alkB gene was 5'ATGGAGCCTAGATAATGAAGT-3' (Wang et al., 2010). A pure culture of Alcanivorax borkumensis Sk2 (Yakimov et al., 1998) was first used to examine the probes before performing the assay, and a culture of Escherichia coli was used as a negative control. Two grams of anhydrite crystals were sonicated for $30 \mathrm{~min}$ in $1 \mathrm{U}$ DNase I solution (Takara, Dalian, China). The crystals were washed with deionized water and then ground into a powder with a BeadBeater in a germ-free environment. The supernatant was mixed with $37 \%$ formaldehyde (final concentration, 1-4\%). To fix the cells in phosphate buffer saline solution, the sample was maintained at $4{ }^{\circ} \mathrm{C}$ for $3-4 \mathrm{~h}$. After centrifugation at $13000 \mathrm{r} \mathrm{min}^{-1}$ for $3 \mathrm{~min}$, the supernatant was discarded. The remaining microbes were soaked in $200 \mu \mathrm{L}$ of PBS buffer, followed by the addition of $200 \mu \mathrm{L}$ of ethanol (Pernthaler et al., 2002). The sample was filtered through $3 \mu \mathrm{m}$ and $0.22 \mu \mathrm{m}$ membranes sequentially (diameter, $25 \mathrm{~mm}$; Millipore, Massachusetts, USA). After dehydration of the membrane using alcohol, $2 \mu \mathrm{L}$ of dying solution containing oligonucleotide probes and $20 \mu \mathrm{L}$ of buffer $(360 \mu \mathrm{L}$ of $5 \mathrm{M} \mathrm{NaCl}, 40 \mu \mathrm{L}$ of $1 \mathrm{M}$ Tris $/ \mathrm{HCl}, 700 \mu \mathrm{L}$ of $100 \%$ formamide, $2 \mu \mathrm{L}$ of $10 \% \mathrm{SD}$ and water to a total volume of $2 \mathrm{~mL}$ ) was added. The hybridization of the probes to the microbes was performed for $2 \mathrm{~h}$ at $46^{\circ} \mathrm{C}$. Rinsing buffer $(700 \mu \mathrm{L}$ of $5 \mathrm{M} \mathrm{NaCl}$, $1 \mathrm{~mL}$ of $1 \mathrm{M}$ Tris $/ \mathrm{HCl}, 500 \mu \mathrm{L}$ of $0.5 \mathrm{M}$ EDTA, $50 \mu \mathrm{L}$ of $10 \%$ SDS and water to a total volume of $50 \mathrm{~mL}$ ) was used to remove free probes. For counterstaining, $50 \mu \mathrm{L}$ of $4^{\prime}, 6^{\prime}-$ diamidino-2-phenylindole (DAPI) (Thermo Fisher Scientific, Massachusetts, USA) solution $\left(1 \mu \mathrm{g} \mathrm{mL}^{-1}\right)$ was added to the sample. After incubation for $3 \mathrm{~min}$, the sample was washed in Milli-Q water (Millipore, Massachusetts, USA) and $96 \%$ ethanol for 1 min (Pernthaler et al., 2002). The microscopic observation was conducted using an Olympus BX51 (Olympus, Tokyo, Japan).

\section{Results}

\subsection{Physicochemical profile and cell counts}

A thick anhydrite layer was present at the bottom of the sediment core based on naked-eye observation of the color and grain size. The anhydrite layer at depths ranging from 177 to $198 \mathrm{~cm}$ consisted of coarse, agglutinated crystals, which corresponded to the high percentage of large grains (78 wt \% larger than $63 \mu \mathrm{m}$ ) (Fig. 2). The XRD analysis further confirmed that the crystals in this layer were anhydrite. In contrast, halite comprised the evaporites at depths of 12, 63, 105 and $222 \mathrm{~cm}$. For the samples at different depths, the 


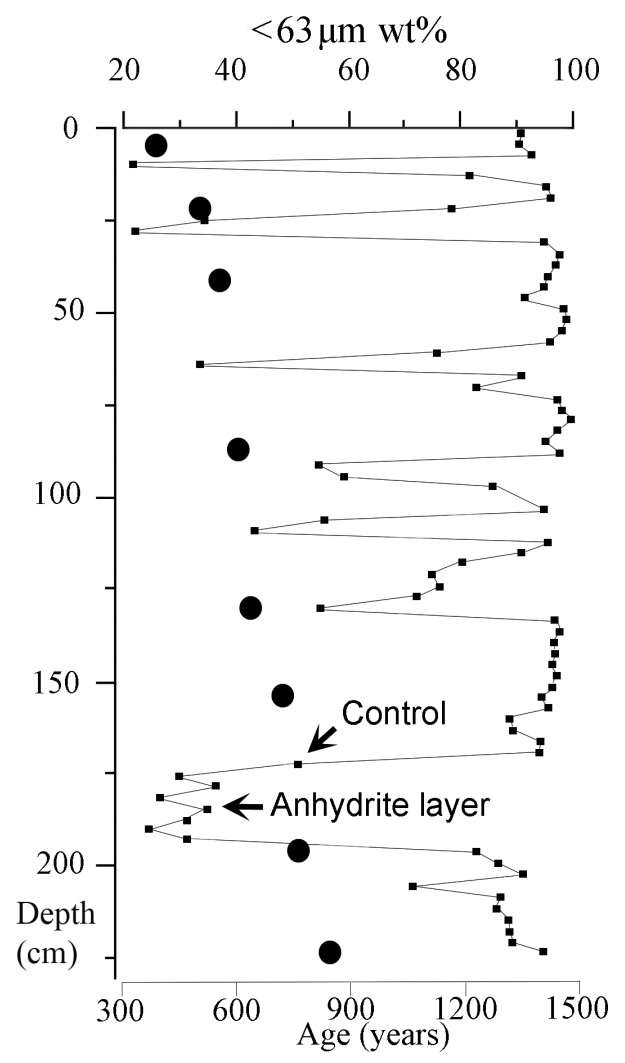

Figure 2. Grain size and age of selected layers The percentages of the small particles $(<63 \mu \mathrm{m})$ in dry weight are shown for 75 slices of the sediment core (small squares on the line). The age estimates (black circles) of the selected layers were performed using radioisotope ${ }^{14} \mathrm{C}$ of the monospecific Globigerinoides sacculifer specimens. Age errors ranged between 25 and 40 years. Anhydrite and control layers for metagenomic study were indicated by arrows.

DOC concentration was measured, and the highest value was recorded at $183 \mathrm{~cm}\left(80.9 \mathrm{mg} \mathrm{L}^{-1}\right)$, which was even higher than the surface layer at $12 \mathrm{~cm}$ (Fig. 3). In the $12 \mathrm{~cm}$ layer, the cell density was $3.2 \times 10^{5}$ cells per $\mathrm{cm}^{3}$, whereas in the layers at $63 \mathrm{~cm}, 105$ and $222 \mathrm{~cm}$, it was reduced by 88,92 and $96 \%$, respectively (Fig. 3). The cell density was also calculated as the number of cells per gram of sediment. The results revealed a value of $7.1 \times 10^{5}$ cells per gram at a depth of $12 \mathrm{~cm}$, which declined more than $70 \%$ in the deeper layers. Although the cell density in the $183 \mathrm{~cm}$ layer $\left(6.7 \times 10^{4}\right.$ cells $\left.\mathrm{cm}^{-3}\right)$ was markedly lower than that in the $12 \mathrm{~cm}$ layer, it was higher than those in the 105 and $222 \mathrm{~cm}$ layers.

The sediment as a whole is a highly reductive environment, as indicated by the low nitrate, low nitrite and extremely high ammonium concentrations (Fig. 3). To determine the time of the anhydrite layers at $177-198 \mathrm{~cm}$, an age estimate was performed for several layers. The sediment ages were estimated based on the radioisotope ${ }^{14} \mathrm{C}$ of $\mathrm{G}$. sacculifer, assuming a linear increment from the top (Fig. 2).
Table 1. Age estimates of the sediment layers.

\begin{tabular}{lrr}
\hline $\begin{array}{l}\text { Layer } \\
(\mathrm{cm})\end{array}$ & $\begin{array}{r}\text { Age } \\
\text { (year) }\end{array}$ & $\begin{array}{r}\text { Age error } \\
\text { (year) }\end{array}$ \\
\hline $3-6$ & 320 & 25 \\
$21-24$ & 475 & 35 \\
$45-48$ & 490 & 30 \\
$90-93$ & 500 & 25 \\
$129-132$ & 560 & 35 \\
$153-156$ & 750 & 30 \\
$198-201$ & 770 & 30 \\
$222-225$ & 880 & 30 \\
\hline
\end{tabular}

Eight sediment layers were selected for the age estimates using radioisotope ${ }^{14} \mathrm{C}$ of $G$. sacculifer collected from the respective layers. The age was corrected by the 400-year reservoir age with an error range.

The results obtained for the layers above and below the anhydrite layer indicated a narrow range of 750-770 years between 153 and $198 \mathrm{~cm}$ (Table 1).

\subsection{Draft genome of the dominant bacterial species in anhydrites}

About $1.8 \mathrm{Gbp}$ Illumina raw sequencing data were obtained for the anhydrite sample and $3.1 \mathrm{Gbp}$ data were obtained for the adjacent control layer. The size of the anhydrite and control metagenomes was 59 and $84 \mathrm{Mbp}$, respectively, after assembly (Table S1 in the Supplement). The microbial communities differed remarkably according to the taxonomic assignment of the 16S/18S rRNA gene fragments in the two metagenomes (Fig. 4). At the genus level, only Ochrobactrum and Alkanindiges were common inhabitants in both samples. Alcanivorax and Bacillus were also dominant genera in the anhydrite and the control, respectively. At the phylum level, excluding the Proteobacteria, the two metagenomes had distinctive phyla. The anhydrite contained archaea that were represented by the methanogenic Methanoculleus (Barret et al., 2012) and fungi that consisted of the Ascomycota. In contrast, the control sediment contained mainly Firmicutes, Bacteroides, Actinobacteria, and Deinococcus-Thermus. At last, an invertebrate species, Prototritia sp. belonging to Arthropoda, was identified in the anhydrite.

\subsection{Genome binning of an Alcanivorax borkumensis genome}

The binned draft genome from the anhydrite metagenome was $3069971 \mathrm{bp}$ and comprised 77 contigs. A partial 16S rRNA gene sequence $(805 \mathrm{bp}$ ) was extracted from the draft genome. Because the sequence was almost identical to that of A. borkumensis Sk2 (99.9\%) (see also genomic alignment in Fig. S2), we considered the binned draft genome to be from a strain of A. borkumensis. As shown in Fig. 5, a phy- 


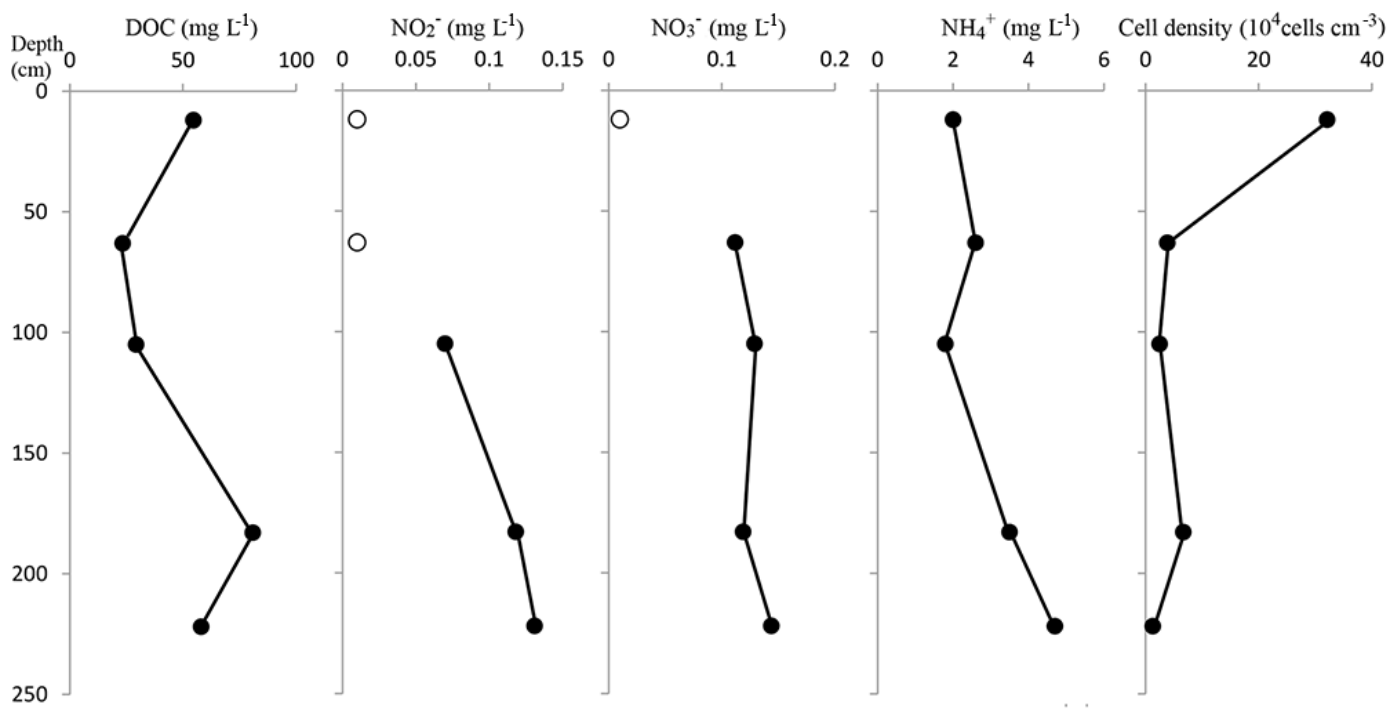

Figure 3. Nutrient measurements and cell counts in the different sediment layers. The pore water samples were analyzed for five layers of a sediment core obtained from the Atlantis II Deep $\left(21^{\circ} 20.76^{\prime} \mathrm{N}, 38^{\circ} 04.68^{\prime} \mathrm{E}\right)$ in 2008 . DOC: dissolved organic carbon.

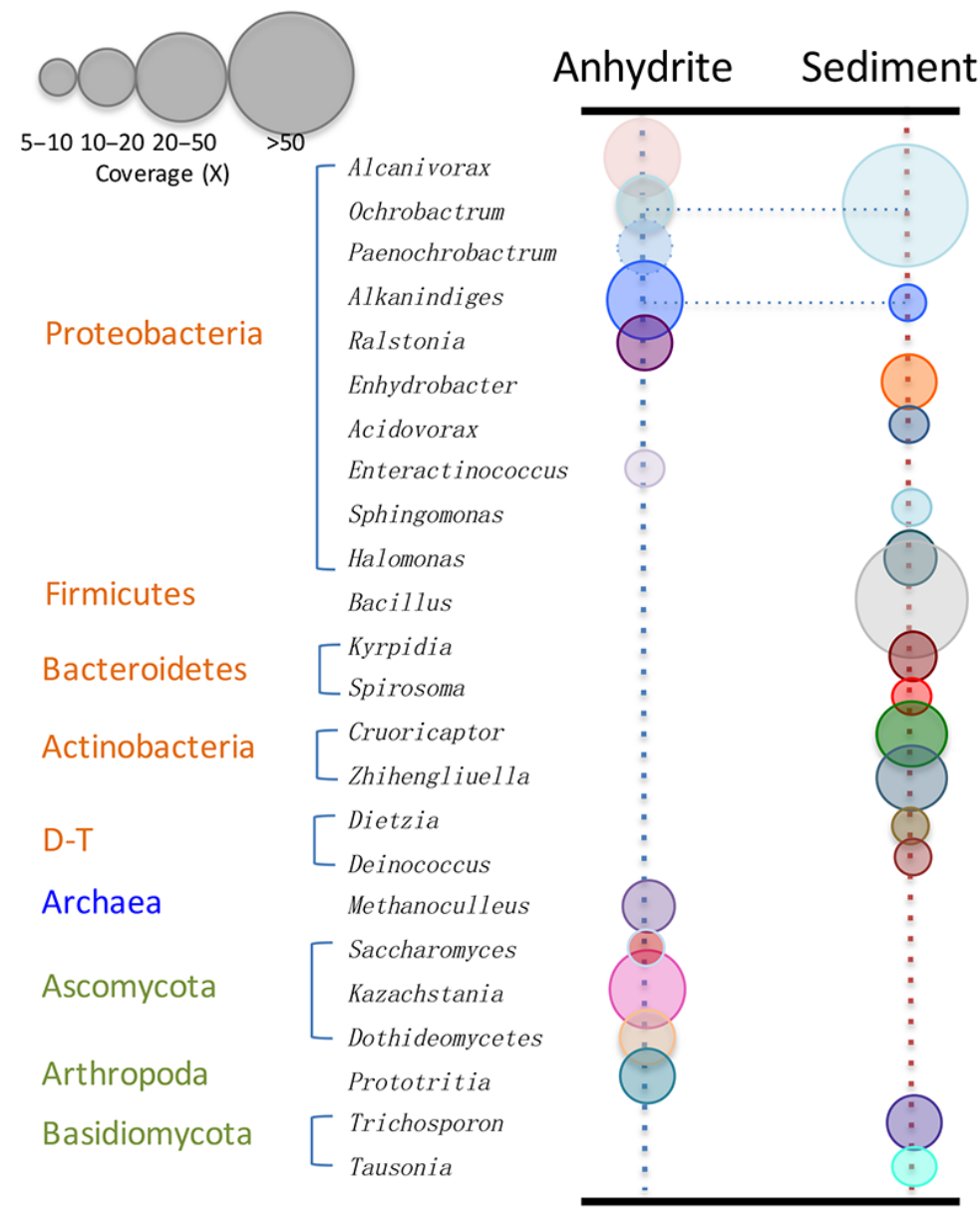

Figure 4. Microbial communities in anhydrite crystals and neighboring control sediment. Phyla and genera in the anhydrite crystals and control layer were predicted using 16S/18S rRNA gene fragments extracted from the corresponding metagenomes (D-T: DeinococcusThermus). The relative abundance of the genera can be estimated by the coverage level $(>5)$ of the $16 \mathrm{~S} / 18 \mathrm{~S}$ rRNA fragments by reads. 


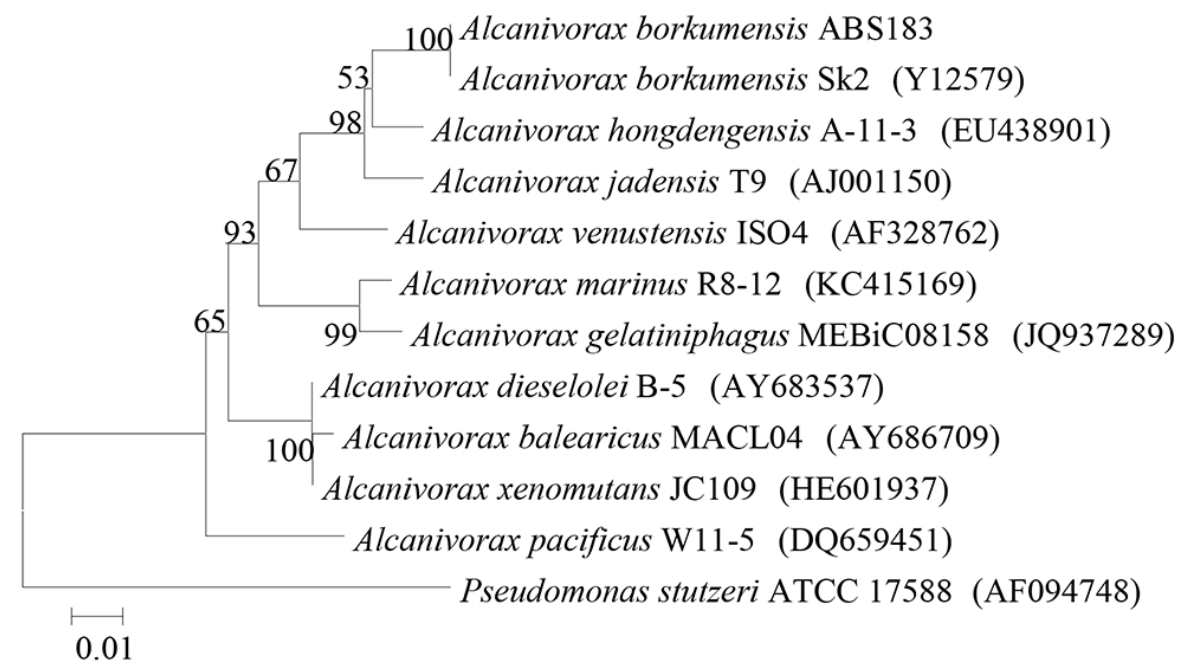

Figure 5. Phylogenetic tree of $16 \mathrm{~S}$ rRNA genes. Bootstrap values (expressed as percentages of 1000 replications) are shown at the branches of the neighbor-joining tree.

logenetic tree based on the 16S rRNA gene sequences of the genus Alcanivorax indicated that the strain clustered with $A$. borkumensis Sk2, an exclusive and ubiquitous hydrocarbondegrading bacterium (Schneiker et al., 2006; Sabirova et al., 2011). The strain name of the A. borkumensis in the sediment core was ABS183. It was the only microbial species that could be reliably separated from the metagenome.

The genome of A. borkumensis ABS183, despite containing gaps, was slightly smaller than that of $A$. borkumensis Sk2 (accession number NC_008260; 3,120,143 bp), suggesting that the draft genome of A. borkumensis ABS183 was nearly complete. Also, there were not detectable alignment gaps between the two genomes (Fig. S2). The identification of a complete list of single-copy genes also supported the completeness of the genome. The DDH estimation between A. borkumensis ABS183 and Sk2 was $97.1 \% \pm 1.3 \%$, which was higher than the standard cut-off value of $70 \%$ for genome relatedness between pairs of species (Wayne et al., 1987). The ANI value between ABS183 and Sk2 was 99.9\%, which was also higher than the standard ANI criterion for species identity (95-96\%) (Richter and RosselloMora, 2009). These results further confirmed that ABS183 was a strain of A. borkumensis.

The genome of A. borkumensis ABS183 contains two copies of the alkane-1 monooxygenase gene (alkA; 10502_28 and 2890_35), which is an essential functional gene for alkane utilization by Alcanivorax bacteria (Fig. 6) (Schneiker et al., 2006). Neighboring the alkA genes, alk$B G H J$ genes, a GntR family transcriptional regulator gene, and a rubredoxin gene were identified. The gene order of the related genes was consistent with that of the homologs in the genome of strain Sk2 (Schneiker et al., 2006). The alk genes were completely absent from the control metagenome. Moreover, the genome of A. borkumensis ABS183 contains genes responsible for the reduction of nitrogen oxides (KEGG genes: K00370-K00374 and K00362-K00363; nitrate reductase I genes and nitrite reductase genes). The reduction process was believed to generate ammonia for the efficient synthesis of amino acids (Schneiker et al., 2006). Ammonia might be generated through nitrate reduction as indicated by the presence of the related genes encoding nitrate and nitrite reduction enzymes (Fig. 6). Ammonia might be imported by transmembrane transporters and assimilated into glutamate. A high demand for fatty acids was a characteristic of A. borkumensis to perform rapid energy and organic carbon storage. A. borkumensis ABS183 was probably able to synthesize long fatty acids because the fas and fabBFGIKZ genes responsible for the elongation of fatty acids were all present in its draft genome. In contrast, the essential fas gene (K11533) and other relevant genes were not found in the control metagenome. Crude oil generally contains aromatic compounds, and the current sediment at the sampling site also contained oil (Wang et al., 2011). As expected, the two metagenomes possessed a complete set of genes responsible for the degradation of aromatic compounds. Based on the homology of the genes, the Ochrobactrum and Alkanindiges species probably played a role in this degradation.

\subsection{Detection of bacteria in anhydrite crystals by DAPI and FISH}

To determine whether complete microbial cells could be maintained in the anhydrite crystals, DAPI and FISH assays were conducted to visualize the microbes. The DAPI results revealed the presence of complete cells that were released or embedded in the crystals (Fig. 7a, d and h). However, the FISH assay, which was used to detect $A$. borkumensis ABS183 with two probes specific to the 16S rRNA gene, 


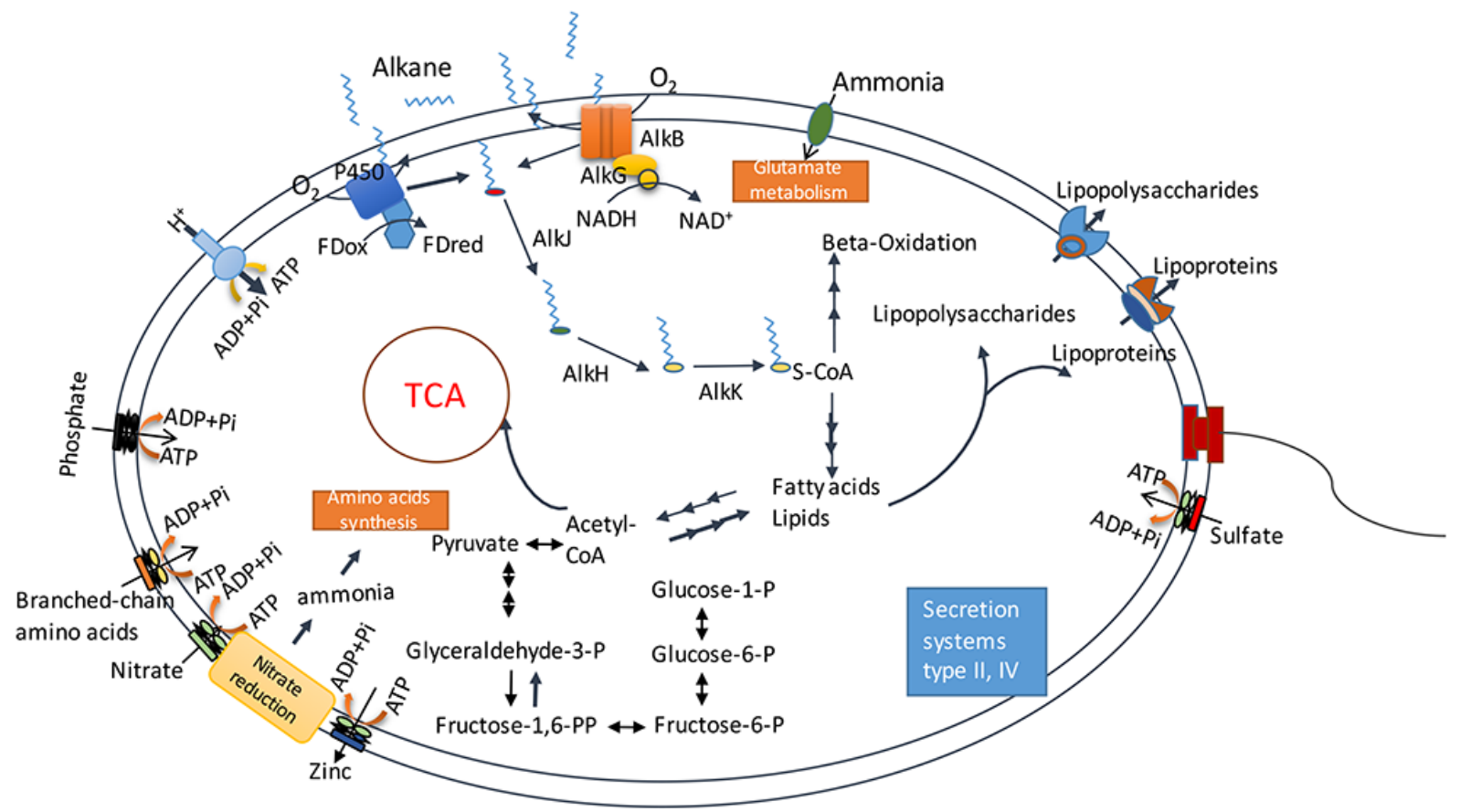

Figure 6. Schematic model of metabolism and cross-membrane transporters. The model was predicted based on the genes in the draft genome of Alcanivorax borkumensis ABS183.

showed some fluorescence-labeled microbes (Fig. 7b, e and i). These microbes could also be envisioned with the FISH assay using the $a l k B$ gene probe (Fig. $7 \mathrm{f}$ and j). The alkB is one of the functional genes that participate in alkane degradation (Schneiker et al., 2006). The rod shape of the fluorescent microbes is consistent with the microscopic features reported previously (Sabirova et al., 2011). These results indicated that some microbes in the microscopic fields were A. borkumensis ABS183, as revealed in the anhydrite metagenome.

\section{Discussion}

In the present study, we detected complete microbial cells and analyzed their metagenome in the anhydrite crystals from a deep-sea anoxic basin. The dominant bacterial species was A. borkumensis ABS183, an aerobic bacterium that is capable of degrading alkanes in crude oil. Alcanivorax is one of the bacterial indicators for the spilling of oil in waters and surface sediment (Yakimov et al., 2007). However, the Atlantis II brine pool is anaerobic and increasingly hydrothermal (Bougouffa et al., 2013b). The brine sediment in the basin was also found to be anoxic. Thus, A. borkumensis ABS183 could not be current inhabitants of the hydrothermal anoxic basin. This difference did not explain the stratification of microbial communities in the different sediment layers of the brine-filled basin. A recent study showed that Alcanivorax was not present in all sediment layers of a sediment core from the Atlantis II basin (Wang et al., 2015). A reason- able explanation for this finding is that the anhydrite layer at $177-198 \mathrm{~cm}$ in the sediment core was formed at a previous benthic site when hydrothermal solution was injected into the seafloor. The organisms living in the benthic water and subsurface sediment were subsequently sealed and protected in the anhydrite crystals. Because the metabolism of A. borkumensis bacteria was specifically used for the degradation of alkanes and other hydrocarbons in crude oil (Yakimov et al., 2007), the benthic site in which the anhydrite layer formed was probably an oil-spilling or oil-forming environment in the Atlantis II basin. The current hot sediments in the basin are biogenic and abiogenic sources of crude oil (Simoneit, 1988). Seeping of the oil has resulted in proliferation of A. borkumensis bacteria in the bottom water. Similarly, oil-utilizing bacteria were nourished after the oil-spilling disaster in the Gulf of Mexico (Gutierrez et al., 2013). The $A$. borkumensis bacteria were important producers of organic carbons as they could convert alkanes and nitrate into organic matter. Fatty acids and lipopolysaccharides that were yielded by A. borkumensis bacteria were nutrients for the whole ecosystem.

Based on the results in the present study, we propose that mild eruptions of hydrothermal solutions injected calciumrich solutions into the seafloor and produced anhydrite veins by mixing with sulfate in the bottom water of the Atlantis II rift basin. The anhydrite layer was then covered by sulfide minerals and biological debris such as the planktonic foraminifera G. sacculifer. In this study, we narrowed the age of the thick anhydrite layer to 750-770 years using the 


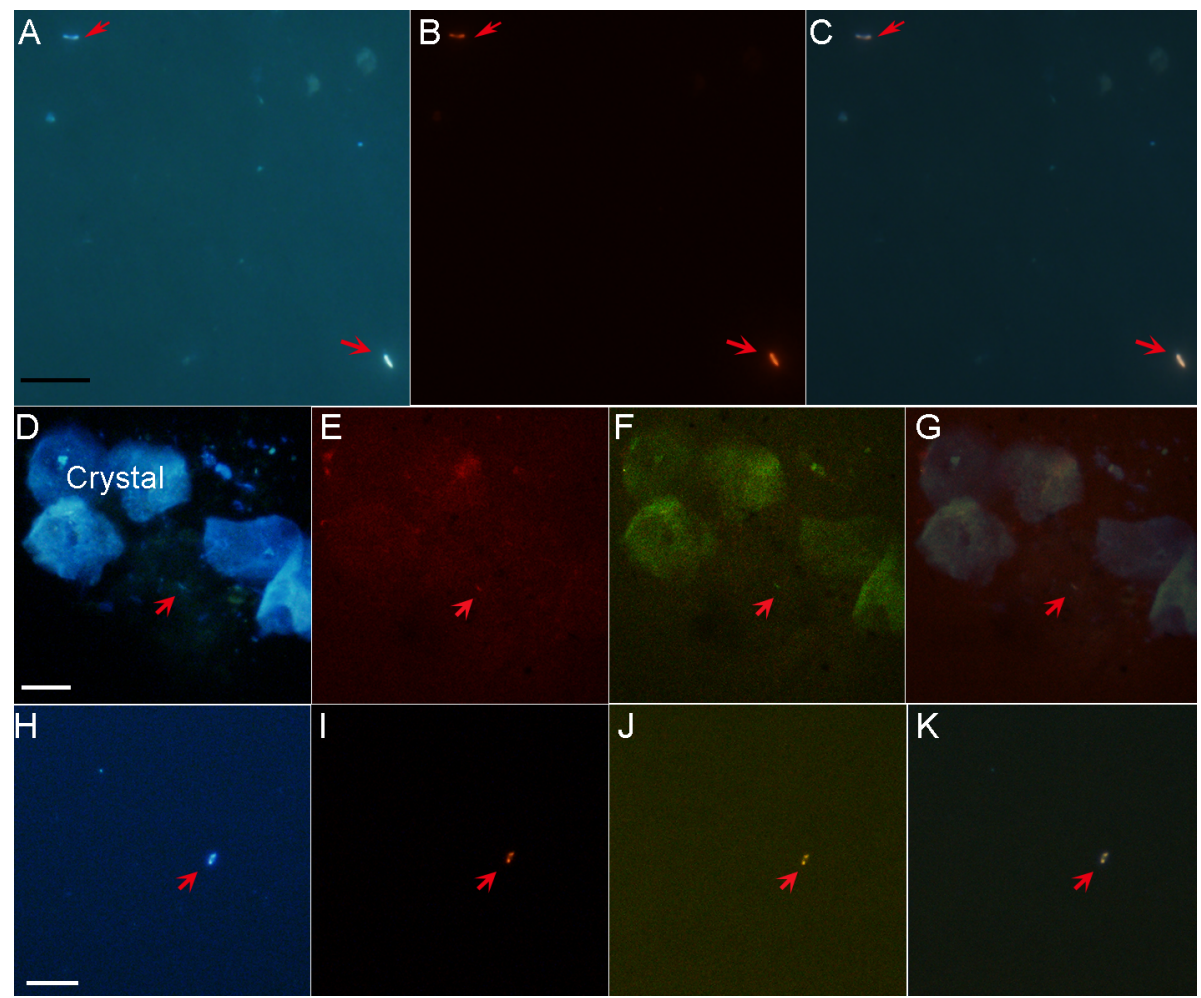

Figure 7. Fluorescence in situ hybridization (FISH) of Alcanivorax borkumensis ABS183 embedded in anhydrite crystals. DAPI staining and FISH using 16S rRNA probes are shown in (a) and (b). The merged image of (a) and (b) is shown in Fig. 7c. DAPI staining and FISH were also performed using two samples that were filtered with $3 \mu \mathrm{m}(\mathbf{d}-\mathbf{g})$ and $0.22 \mu \mathrm{m}(\mathbf{h}-\mathbf{k})$ membranes, respectively. Alcanivorax bacteria were released from the large crystals filtered through the $3 \mu \mathrm{m}$ membranes (d-g). The bacteria were stained with DAPI (d), Alcanivorax borkumensis ABS183 probes (f) and the alkB probe (f), respectively, and overlaid (g). Using a sample filtered through a $0.22 \mu \mathrm{m}$ membrane, a dividing Alcanivorax borkumensis ABS183 cell was labeled using the same method and probes (h-j). The microscopic fields shown in (h) $-(\mathbf{j})$ are merged in $(\mathbf{k})$.

${ }^{14} \mathrm{C}$ isotope of the G. sacculifer specimens. This result also indicates a relatively young sediment age and a high accumulation rate of precipitated metals in the Atlantis II basin. Because the upward movement of hydrothermal solutions might transfer some foraminifera specimens from lower layers to the anhydrite layer, we did not use the foraminifera between anhydrite crystals. In our previous study, we showed evidence of oil formation in the Atlantis II brine pool (Wang et al., 2011). The organic carbon content can be converted to aromatic compounds under the hydrothermal conditions in the pool based on chemical and metagenomic evidence (Wang et al., 2011). However, the bottom of the anoxic brine pool was not a habitat of Alcanivorax species (Bougouffa et al., 2013a; Blanc and Anschutz, 1995), suggesting that Alcanivorax flourished in the basin before the formation of brine water layers over the sediment (Blanc and Anschutz, 1995).

Although there were differences in microbial communities between the anhydrite crystals and the control sediment, Ochrobactrum sp. was one of the common inhabitants. Previous studies have shown that Ochrobactrum species could me- tabolize aromatic compounds aerobically and anaerobically (Zu et al., 2014; Mahmood et al., 2009), which explains their presence in both metagenomes assessed in the current study. Moreover, we determined the concentrations of nitrogen oxides in the different sulfide layers, although only low concentrations were detected. Ochrobactrum species were potentially able to anaerobically degrade polycyclic aromatic compounds using nitrate as an oxygen donor (Mahmood et al., 2009; Wu et al., 2009). Such a chemolithoheterotrophic lifestyle is in accordance with the current in situ environment of the sediment in the Atlantis II. Regardless of the environmental changes indicated by the findings in the present study, the spreading of Ochrobactrum sp. was seemingly not affected. Although the metagenomes in the present study contained an abundance of essential genes for degrading a variety of aromatic compounds, the microbial degradation of these compounds might have been attenuated by a lack of oxygen and a high level of salinity (Klinkhammer and Lambert, 1989). Anaerobic degradation of compounds is more difficult than aerobic degradation, often requiring oxygen donors such as nitrate and sulfate (Mahmood et al., 2009; 
Wu et al., 2009). Based on its ability to survive under anoxic conditions, Ochrobactrum sp. is probably able to maintain a higher level of fitness in the control sediment compared with Alcanivorax. In the present study, the Alkanindiges identified in both metagenomes was also a well-known alkane degrader (Klein et al., 2007; Bogan et al., 2003). Because of its presence in both anhydrites and the adjacent sulfide layer, we assumed that the Alkanindiges bacterium was also capable of surviving aerobically and anaerobically in the oil-producing sediment. Hence, the change from an oxic to an anoxic benthic environment caused a dramatic shift in the microbial communities, resulting in the extinction of the obligate aerobic alkane-utilizer Alcanivorax and continuous residency of anaerobic oil-degraders. The availability of nitrogen oxides and the dissolution of sulfate from anhydrite crystals were possibly critical to the metabolic activities of the anaerobes. In addition, the Bacillus and fungi present in the control sediment were probably present in the form of dormant spores. In a recent report, Ochrobactrum and Bacillus were confirmed to be dominant species in some upper sulfide layers in the Atlantis II (Wang et al., 2015). Altogether, in the present study, the current microbial inhabitants in the sulfide layers were largely different from those in the anhydrite crystals.

The geochemical data collected herein suggested that the sub-superficial anhydrite layer could release organic carbon contents into the sediment, as reported previously. Our measurement of DOC at $80.9 \mathrm{mg} \mathrm{L}^{-1}$ in the anhydrite layer was higher than the generally accepted maximum value of $50 \mathrm{~m} \mathrm{~L}^{-1}$ for marine sediments (Cameron et al., 2006). The abnormally high DOC was considered a notable alteration of the local environments and probably resulted from the breakdown of anhydrite crystals. Anhydrites in the Atlantis II brine sediment were likely maintained by the high salinity and temperature and then slowly dissolved. This phenomenon may be explained by the slight undersaturation of the anhydrite in the Atlantis II sediment (Anschutz et al., 2000). Such anhydrite layers are widely distributed in Middle Eastern sediments (Alsharhan and Nairn, 1997). Hence, our findings shed light on the formation of micro-environments by anhydrite evaporites in the deep sediments. In this study, there was an inconsistency between the cell density and the DOC at the $12 \mathrm{~cm}$ depth layer, in which the DOC could not support a 10-fold higher biomass. This phenomenon probably resulted from the formation of petroleum compounds under the hydrothermal effects (Wang et al., 2011). In the petroleum, hydrophobic organic compounds (HOCs) consisting of polycyclic aromatic hydrocarbons (PAHs) could not be counted in our DOC measurements (J. Pearsons, personal communication, 2014). The nutrient supply is critical for microbes to survive in deep-sea sediment. Apart from the chemolithoautotrophic microbes, numerous other inhabitants take advantage of the buried organic matter. Importantly, the trapped organic matter serves as a nutrient supply following the dissolution of organic-rich anhydrite crystals. Therefore, our findings highlighted the importance of the nutrients released from the anhydrite facies for microbes in deep-sea subsuperficial sediment.

\section{Data availability}

Illumina raw data will be accessible under SRA356974 in the NCBI SRA database. A. borkumensis ABS183 genome was deposited in the NCBI database: BioProject LKAP00000000.

\section{The Supplement related to this article is available online at doi:10.5194/bg-13-6405-2016-supplement.}

Author contributions. Yong Wang, Tie Gang Li and Pei-Yuan Qian were responsible for the study design. Data analysis was performed by Yong Wang, Tie Gang Li, Jiao Tao Li, Qi Liang Lai and Zhao Ming Gao. Meng Ying Wang conducted the FISH assays. The paper was prepared by Yong Wang with contributions from all coauthors.

Acknowledgements. This study was supported by the National Science Foundation of China no. 41476104 and no. 31460001 to Yong Wang, and the King Abdullah University of Science and Technology (SA-C0040/UK-C0016) to Pei-Yuan Qian. This work was also supported by Hainan international collaborative grant no. KJHZ2015-22.

Edited by: T. Treude

Reviewed by: M. Bomberg and one anonymous referee

\section{References}

Albertsen, M., Hugenholtz, P., Skarshewski, A., Nielsen, K. L., Tyson, G. W., and Nielsen, P. H.: Genome sequences of rare, uncultured bacteria obtained by differential coverage binning of multiple metagenomes, Nat. Biotechnol., 31, 533-538, doi:10.1038/Nbt.2579, 2013.

Alsharhan, A. S. and Nairn, A. E. M.: Sedimentary basins and petroleum geology of the Middle East, Elsevier Science BV, Amsterdam, 1997.

Anschutz, P. and Blanc, G.: Heat and salt fluxes in the Atlantis II Deep (Red Sea), Earth Planet Sc. Lett., 142, 147-159, 1996.

Anschutz, P., Blanc, G., Monnin, C., and Boulègue, J.: Geochemical dynamics of the Atlantis II Deep (Red Sea): II. Composition of metalliferous sediment pore waters, Geochim. Cosmochim. Ac., 64, 3995-4006, 2000.

Auch, A. F., Klenk, H. P., and Goker, M.: Standard operating procedure for calculating genome-to-genome distances based on highscoring segment pairs, Standards in Genomic Science, 2, 142148, doi:10.4056/sigs.541628, 2010a. 
Auch, A. F., von Jan, M., Klenk, H. P., and Goker, M.: Digital DNADNA hybridization for microbial species delineation by means of genome-to-genome sequence comparison, Standards in Genomic Science, 2, 117-134, doi:10.4056/sigs.531120, 2010 b.

Babel, M.: Models for evaporite, selenite and gypsum microbialite deposition in ancient saline basins, Acta Geol. Pol., 54, 219-249, 2004.

Bard, E.: Correction of accelerator mass spectrometry ${ }^{14} \mathrm{C}$ ages measured in planktonic foraminifera: Paleoceanographic implications, Paleoceanography, 3, 635-645, 1988.

Barret, M., Gagnon, N., Morissette, B., Topp, E., Kalmokoff, M., Brooks, S. P. J., Matias, F., Massé, D. I., Masse, L., and Talbot, G.: Methanoculleus spp. as a biomarker of methanogenic activity in swine manure storage tanks, FEMS Microbiol. Ecol., 80, 427440, doi:10.1111/j.1574-6941.2012.01308.x, 2012.

Benison, K. C., Jagniecki, E. A., Edwards, T. B., Mormile, M. R., and Storrie-Lombardi, M. C.: "Hairy blobs": microbial suspects preserved in modern and ancient extremely acid lake evaporites, Astrobiology, 8, 807-821, doi:10.1089/ast.2006.0034, 2008.

Blanc, G. and Anschutz, P.: New stratification in the hydrothermal brine system of the Atlantis II Deep, Red Sea, Geology, 23, 543546, 1995.

Bogan, B. W., Sullivan, W. R., Kayser, K. J., Derr, K. D., Aldrich, H. C., and Paterek, J. R.: Alkanindiges illinoisensis gen. nov., sp. nov., an obligately hydrocarbonoclastic, aerobic squalanedegrading bacterium isolated from oilfield soils, Int. J. Syst. Evol. Microbiol., 53, 1389-1395, doi:10.1099/ijs.0.02568-0, 2003.

Bougouffa, S., Yang, J. K., Lee, O. O., Wang, Y., Batang, Z., AlSuwailem, A., and Qian, P. Y.: Distinctive microbial community structure in highly stratified deep-sea brine water columns, Appl. Environ. Microbiol., 79, 3425-3437, doi:10.1128/aem.0025413, 2013a.

Bougouffa, S., Yang, J. K., Lee, O. O., Wang, Y., Batang, Z., AlSuwailem, A., and Qiana, P. Y.: Distinctive microbial community structure in highly stratified deep-sea brine water columns, Appl. Environ. Microb., 79, 3425-3437, doi:10.1128/Aem.00254-13, $2013 b$.

Bower, A. S.: R/V Oceanus Voyage 449-6 Red Sea Atlantis II Deep Complex Area 19 October-1 November 2008, Woods Hole Oceanographic Institution, 2009.

Brocks, J. J., Love, G. D., Summons, R. E., Knoll, A. H., Logan, G. A., and Bowden, S. A.: Biomarker evidence for green and purple sulphur bacteria in a stratified Palaeoproterozoic sea, Nature, 437, 866-870, 2005.

Cameron, D., Willett, M., and Hammer, L.: Distribution of organic carbon in the Berkeley Pit lake, Butte, Montana, Mine Water Environ., 25, 93-99, doi:10.1007/s10230-006-0116-4, 2006.

Dupraz, C., Reid, R. P., and Visscher, P. T.: Microbialites, modern, in: Encyclopaedia of Geobiology, edited by: Reitner, V., and Thiel, J., Springer, Heidelberg, 617-635, 2011.

Girdler, R. W.: A review of Red Sea heat flow, Philos. Tr. R. Soc. Lond., 267, 191-203, 1970.

Goris, J., Konstantinidis, K. T., Klappenbach, J. A., Coenye, T., Vandamme, P., and Tiedje, J. M.: DNA-DNA hybridization values and their relationship to whole-genome sequence similarities, Int. J. Syst. Evol. Microbiol., 57, 81-91, 2007.

Gough, H. L. and Stahl, D. A.: Optimization of direct cell counting in sediment, J. Microbiol. Methods, 52, 39-46, 2003.
Gutierrez, T., Singleton, D. R., Berry, D., Yang, T., Aitken, M. D., and Teske, A.: Hydrocarbon-degrading bacteria enriched by the Deepwater Horizon oil spill identified by cultivation and DNASIP, ISME J., 7, 2091-2104, doi:10.1038/ismej.2013.98, 2013.

Hill, A. E.: The transition temperature of gypsum to anhydrite, J. Am. Chem. Soc., 59, 2242-2244, doi:10.1021/ja01290a039, 1937.

Huang, Y., Gilna, P., and Li, W.: Identification of ribosomal RNA genes in metagenomic fragments, Bioinformatics, 25, 13381340, 2009.

Hyatt, D., Chen, G. L., LoCascio, P. F., Land, M. L., Larimer, F. W., and Hauser, L. J.: Prodigal: prokaryotic gene recognition and translation initiation site identification, BMC Bioinformatics, 11, 2010.

Jannasch, H. W. and Mottl, M. J.: Geomicrobiology of deep-sea hydrothermal vents, Science, 229, 717-725, doi:10.1126/science.229.4715.717, 1985.

Kanehisa, M., Goto, S., Sato, Y., Furumichi, M., and Tanabe, M.: KEGG for integration and interpretation of large-scale molecular data sets, Nucleic Acids Res., 40, 109-114, 2012.

Kim, O. S., Cho, Y. J., Lee, K., Yoon, S. H., Kim, M., Na, H., Park, S. C., Jeon, Y. S., Lee, J. H., Yi, H., Won, S., and Chun, J.: Introducing EzTaxon-e: a prokaryotic 16S rRNA gene sequence database with phylotypes that represent uncultured species, Int. J. Syst. Evol. Microbiol., 62, 716-721, doi:10.1099/ijs.0.0380750, 2012

Klein, A. N., Frigon, D., and Raskin, L.: Populations related to Alkanindiges, a novel genus containing obligate alkane degraders, are implicated in biological foaming in activated sludge systems, Environ. Microbiol., 9, 1898-1912, doi:10.1111/j.14622920.2007.01307.x, 2007.

Klinkhammer, G. P. and Lambert, C. E.: Preservation of organic matter during salinity excursions, Nature, 339, 271-274, 1989.

Kristall, B., Kelley, D. S., Hannington, M. D., and Delaney, J. R.: Growth history of a diffusely venting sulfide structure from the Juan de Fuca Ridge: A petrological and geochemical study, Geochem. Geophys. Geosyst., 7, Q07001, doi:10.1029/2005gc001166, 2006.

Krogh, A., Brown, M., Mian, I. S., Sjölander, K., and Haussler, D.: Hidden markov models in computational biology, J. Mol. Biol., 235, 1501-1531, 1994.

Li, H., Handsaker, B., Wysoker, A., Fennell, T., Ruan, J., Homer, N., Marth, G., Abecasis, G., and Durbin, R.: The sequence alignment/map format and SAMtools, Bioinformatics, 25, 2078 2079, doi:10.1093/bioinformatics/btp352, 2009.

Ludwig, W., Strunk, O., Westram, R., Richter, L., Meier, H., Yadhukumar, Buchner, A., Lai, T., Steppi, S., Jobb, G., Forster, W., Brettske, I., Gerber, S., Ginhart, A. W., Gross, O., Grumann, S., Hermann, S., Jost, R., Konig, A., Liss, T., Lussmann, R., May, M., Nonhoff, B., Reichel, B., Strehlow, R., Stamatakis, A., Stuckmann, N., Vilbig, A., Lenke, M., Ludwig, T., Bode, A., and Schleifer, K.-H.: ARB: a software environment for sequence data, Nucl. Acids Res., 32, 1363-1371, doi:10.1093/nar/gkh293, 2004.

Mahmood, Q., Hu, B., Cai, J., Zheng, P., Azim, M. R., Jilani, G., and Islam, E.: Isolation of Ochrobactrum sp.QZ2 from sulfide and nitrite treatment system, J. Hazard. Mater., 165, 558-565, 2009. 
Meier-Kolthoff, J. P., Auch, A. F., Klenk, H. P., and Goker, M.: Genome sequence-based species delimitation with confidence intervals and improved distance functions, BMC Bioinfo, 14, doi:10.1186/1471-2105-14-60, 2013.

Missack, E., Stoffers, P., and El Goresy, A.: Mineralogy, paragenesis, and phases relations of copper iron sulfides in the Atlantis II Deep, Red. Sea, Miner. Deposita, 24, 82-91, 1989.

Nurk, S., Bankevich, A., Antipov, D., Gurevich, A. A., Korobeynikov, A., Lapidus, A., Prjibelski, A. D., Pyshkin, A., Sirotkin, A., Sirotkin, Y., Stepanauskas, R., Clingenpeel, S. R., Woyke, T., McLean, J. S., Lasken, R., Tesler, G., Alekseyev, M. A., and Pevzner, P. A.: Assembling single-cell genomes and mini-metagenomes from chimeric MDA products, J. Comput. Biol., 20, 714-737, doi:10.1089/cmb.2013.0084, 2013.

Orcutt, B. N., Sylvan, J. B., Knab, N. J., and Edwards, K. J.: Microbial ecology of the dark ocean above, at, and below the seafloor, Microbiol. Mol. Biol. Rev., 75, 361-422, doi:10.1128/Mmbr.00039-10, 2011.

Oudin, E., Thisse, Y., and Ramboz, C.: Fluid inclusion and mineralogical evidence for high temperature saline hydrothermal circulation in the Red Sea metalliferous sediments: preliminary results, Mar. Mining, 5, 3-31, 1984.

Overbeek, R., Begley, T., Butler, R. M., Choudhuri, J. V., Chuang, H. Y., Cohoon, M., de Crecy-Lagard, V., Diaz, N., Disz, T., Edwards, R., Fonstein, M., Frank, E. D., Gerdes, S., Glass, E. M., Goesmann, A., Hanson, A., Iwata-Reuyl, D., Jensen, R., Jamshidi, N., Krause, L., Kubal, M., Larsen, N., Linke, B., McHardy, A. C., Meyer, F., Neuweger, H., Olsen, G., Olson, R., Osterman, A., Portnoy, V., Pusch, G. D., Rodionov, D. A., Ruckert, C., Steiner, J., Stevens, R., Thiele, I., Vassieva, O., Ye, Y., Zagnitko, O., and Vonstein, V.: The subsystems approach to genome annotation and its use in the project to annotate 1000 genomes, Nucl. Acids Res., 33, 5691-5702, 2005.

Parkes, R. J., Cragg, B. A., and Wellsbury, P.: Recent studies on bacterial populations and processes in subseafloor sediments: A review, Hydrogeol. J., 8, 11-28, doi:10.1007/p100010971, 2000.

Pernthaler, A., Pernthaler, J., and Amann, R.: Fluorescence in situ hybridization and catalyzed reporter deposition for the identification of marine bacteria, Appl. Environ. Microbiol., 68, 30943101, 2002.

Petrash, D. A., Gingras, M. K., Lalonde, S. V., Orange, F., Pecoits, E., and Konhauser, K. O.: Dynamic controls on accretion and lithification of modern gypsum-dominated thrombolites, Los Roques, Venezuela, Sediment Geol., 245/246, 29-47, 2012.

Quast, C., Pruesse, E., Yilmaz, P., Gerken, J., Schweer, T., Yarza, P., Peplies, J., and Glöckner, F. O.: The SILVA ribosomal RNA gene database project: improved data processing and web-based tools, Nucl. Acids Res., 41, D590-D596, doi:10.1093/nar/gks1219, 2013.

R Core Team: R: A language and environment for statistical computing, R Foundation for Statistical Computing, Vienna, Austria. ISBN 3-900051-07-0, http://www.R-project.org/, 2013.

Ramboz, C., Oudin, E., and Thisse, Y.: Geyser-type discharge in Atlantis II Deep, Red Sea: evidence of boiling from fluid inclusions in epigenetic anhydrite, Can. Mineral., 26, 765-786, 1988.

Reimer, P. J., Baillie, M. G. L., Bard, E., Bayliss, A., Beck, J. W., Blackwell, P. G., Ramsey, C. B., Buck, C. E., Burr, G. S., Edwards, R. L., Friedrich, M., Grootes, P. M., Guilderson, T. P., Hajdas, I., Heaton, T. J., Hogg, A. G., Hughen, K. A., Kaiser,
K. F., Kromer, B., McCormac, F. G., Manning, S. W., Reimer, R. W., Richards, D. A., Southon, J. R., Talamo, S., Turney, C. S. M., van der Plicht, J., and Weyhenmeyer, C. E.: IntCal09 and Marine09 radiocarbon age calibration curves, 0-50 000 years cal BP, Radiocarbon, 51, 1111-1150, 2009.

Richter, M. and Rossello-Mora, R.: Shifting the genomic gold standard for the prokaryotic species definition, Proc. Natl. Acad. Sci USA, 106, 19126-19131, doi:10.1073/pnas.0906412106, 2009.

Sabirova, J. S., Becker, A., Lunsdorf, H., Nicaud, J. M., Timmis, K. N., and Golyshin, P. N.: Transcriptional profiling of the marine oil-degrading bacterium Alcanivorax borkumensis during growth on n-alkanes, FEMS Microbiol. Lett., 319, 160-168, doi:10.1111/j.1574-6968.2011.02279.x, 2011.

Schardt, C.: Hydrothermal fluid migration and brine pool formation in the Red Sea: the Atlantis II Deep, Miner. Deposita, 51, 89111, doi:10.1007/s00126-015-0583-2, 2016.

Schloss, P. D., Westcott, S. L., Ryabin, T., Hall, J. R., Hartmann, M., Hollister, E. B., Lesniewski, R. A., Oakley, B. B., Parks, D. H., Robinson, C. J., Sahl, J. W., Stres, B., Thallinger, G. G., Van Horn, D. J., and Weber, C. F.: Introducing mothur: Open-source, platform-independent, community-supported software for describing and comparing microbial communities, Appl. Environ. Microbiol., 75, 7537-7541, doi:10.1128/aem.01541-09, 2009.

Schneiker, S., Martins dos Santos, V. A., Bartels, D., Bekel, T., Brecht, M., Buhrmester, J., Chernikova, T. N., Denaro, R., Ferrer, M., Gertler, C., Goesmann, A., Golyshina, O. V., Kaminski, F., Khachane, A. N., Lang, S., Linke, B., McHardy, A. C., Meyer, F., Nechitaylo, T., Puhler, A., Regenhardt, D., Rupp, O., Sabirova, J. S., Selbitschka, W., Yakimov, M. M., Timmis, K. N., Vorholter, F. J., Weidner, S., Kaiser, O., and Golyshin, P. N.: Genome sequence of the ubiquitous hydrocarbon-degrading marine bacterium Alcanivorax borkumensis, Nat. Biotechnol., 24, 997-1004, doi:10.1038/nbt1232, 2006.

Shipboard Scentific Party: Red Sea: Site 226, in: Deep Sea Drilling Project, 595-600, 1974.

Simoneit, B. R. T.: Petroleum generation submarine hydrothermal systems: An update, Can. Mineral., 26, 827-840, 1988.

Swallow, J. C. and Crease, J.: Hot salty water at the bottom of the Red Sea, Nature, 205, 165-166, 1965.

Taher, A. G.: Microbially induced sedimentary structures in evaporite-siliciclastic sediments of Ras Gemsa sabkha, Red Sea Coast, Egypt, J. Adv. Res., 5, 577-586, 2014.

Tamura, K., Peterson, D., Peterson, N., Stecher, G., Nei, M., and Kumar, S.: MEGA5: molecular evolutionary genetics analysis using maximum likelihood, evolutionary distance, and maximum parsimony methods, Mol. Biol. Evol., 28, 2731-2739, 2011.

Teske, A. and Sorensen, K. B.: Uncultured archaea in deep marine subsurface sediments: have we caught them all?, ISME J., 2, 318, doi:10.1038/ismej.2007.90, 2007.

Trichet, J., Défarge, C., Tribble, J., Tribble, G. W., and Sansone, F. J.: Christmas Island lagoonal lakes, models for the deposition of carbonate-evaporite-organic laminated sediments, Sediment. Geol., 140, 177-189, 2001.

Wang, W., Wang, L., and Shao, Z.: Diversity and abundance of oildegrading bacteria and alkane hydroxylase (alkB) genes in the subtropical seawater of Xiamen Island, Microb. Ecol., 60, 429439, doi:10.1007/s00248-010-9724-4, 2010.

Wang, Y., Yang, J., Lee, O. O., Dash, S., Lau, S. C. K., AlSuwailem, A., Wong, T. Y. H., Danchin, A., and Qian, P.-Y.: Hy- 
drothermally generated aromatic compounds are consumed by bacteria colonizing in Atlantis II Deep of the Red Sea, ISME J., 5, 1652-1659, doi:10.1038/ismej.2011.42, 2011.

Wang, Y., Li, J. T., He, L. S., Yang, B., Gao, Z. M., Cao, H. L., Batang, Z., Al-Suwailem, A., and Qian, P. Y.: Zonation of microbial communities by a hydrothermal mound in the Atlantis II Deep (the Red Sea), PLoS ONE, 10, e0140766, doi:10.1371/journal.pone.0140766, 2015.

Wang, Y., Gao, Z. M., Xu, Y., Li, G. Y., He, L. S., and Qian, P. Y.: An evaluation of multiple annealing and looping based genome amplification using a synthetic bacterial community, ACTA Oceanol. Sin., 35, 131-136, 2016.

Wayne, L. G., Brenner, D. J., Colwell, R. R., Grimont, P. A. D., Kandler, O., Krichevsky, M. I., Moore, L. H., Moore, W. E. C., Murray, R. G. E., Stackebrandt, E., Starr, M. P., and Trüper, H. G.: Report of the ad hoc committee on reconciliation of approaches to bacterial systematics, Int. J. Syst. Bacteriol., 37, 463-464, 1987.

Webster, G., John Parkes, R., Cragg, B. A., Newberry, C. J., Weightman, A. J., and Fry, J. C.: Prokaryotic community composition and biogeochemical processes in deep subseafloor sediments from the Peru Margin, FEMS Microbiol. Ecol., 58, 65-85, doi:10.1111/j.1574-6941.2006.00147.x, 2006.
Wu, Y., He, T., Zhong, M., Zhang, Y., Li, E., Huang, T., and Hu, Z.: Isolation of marine benzo[a]pyrene-degrading Ochrobactrum sp. BAP5 and proteins characterization, J. Environ. Sci., 21, 14461451, 2009.

Yakimov, M. M., Golyshin, P. N., Lang, S., Moore, E. R. B., Abraham, W.-R., Lünsdorf, H., and Timmis, K. N.: Alcanivorax borkumensis gen. nov., sp. nov., a new, hydrocarbondegrading and surfactant-producing marine bacterium, Int. J. Syst. Evol. Microbiol., 48, 339-348, doi:10.1099/00207713-482-339, 1998.

Yakimov, M. M., Timmis, K. N., and Golyshin, P. N.: Obligate oildegrading marine bacteria, Curr. Opin. Biotech., 18, 257-266, 2007.

Zierenberg, R. A. and Shanks, W. C.: Mineralogy and geochemistry of epigenetic features in metalliferous sediment, Atlantis II Deep, Red Sea, Econ. Geol., 78, 57-72, doi:10.2113/gsecongeo.78.1.57, 1983.

Zong, C., Lu, S., Chapman, A. R., and Xie, X. S.: Genomewide detection of single-nucleotide and copy-number variations of a single human cell, Science, 338, 1622-1626, doi:10.1126/science.1229164, 2012.

Zu, L., Xiong, J., Li, G., Fang, Y., and An, T.: Concurrent degradation of tetrabromobisphenol A by Ochrobactrum sp. T under aerobic condition and estrogenic transition during these processes, Ecotox Environ Safety, 104, 220-225, doi:10.1016/j.ecoenv.2014.03.015, 2014. 